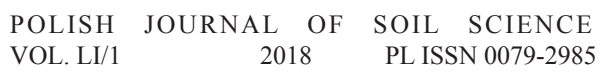

DOI: $10.17951 / \mathrm{pjss} / 2018.51 .1 .11$

\title{
MAGDALENA DZIĘGIELEWSKA*, ANDRZEJ SKWIERCZ** \\ THE INFLUENCE OF SELECTED ABIOTIC FACTORS ON THE OCCURRENCE OF ENTOMOPATHOGENIC NEMATODES (STEINERNEMATIDAE, HETERORHABDITIDAE) IN SOIL
}

\begin{abstract}
Original research confirms a significant impact of abiotic factors, such as soil type and physicochemical properties, on the biological activity and infectivity of entomopathogenic nematodes from the Steinernematidae and Heterorhabditidae families. Nematodes were found to prefer sandy loam soils; however, the highest species diversity was found in sandy soils. Some species of nematodes were associated with a specific type of soil. For example, Steinernema silvaticum and Heterorhabditis bacteriophora were found only in sands, and H. megidis predominantly in clay. Nematodes were found in soils of varying $\mathrm{pH}$ levels, although individual species preferred a certain degree of acidity. S. bicornutum and H. megidis were found only in alkaline soils, while others, such as $\mathrm{S}$. silvaticum, only in acidic environments $(\mathrm{pH}<4.5)$.
\end{abstract}

Keywords: entomopathogenic nematodes, soil texture, soil moisture, soil salinity, pH, environment interactions

\section{INTRODUCTION}

Nematodes of the family Steinernematidae Chitwood \& Chitwood (1937) and Heterorhabditidae Poinar (1976), that parasitize insects, known as entomopathogenic nematodes (EPNs) (Adenophorea: Rhabditida), are widely distrib-

* Department of Plant Physiology and Biochemistry, West Pomeranian University of Technology in Szczecin.

** Department of Phytopathology, Entomology and Molecular Diagnostics, University of Warmia-Mazury, entomology@zut.edu.pl 
uted all over the world (Hominic 2002, Adams et al. 2006). These animals are widely used because of their special attributes such as their wide range of potential hosts, effectiveness at limiting populations of noxious insects, possibility of massive production through solid and liquid growth mediums, and overall environmental safety (Grewal et al. 2005, Grewal 2012). High nematode activity in the soil is a necessary condition to maintain a robust nematode population in the environment. One of the most important conditions for nematode development in the soil is the presence of their favored hosts (Peters 1996, Mráček et al. 1999, Mráček and Bečvár 2000). The other important conditions are: the type and structure of the soil, physicochemical properties, such as soil moisture, temperature, aeration and acidity (Kaya 1990, Kung et al. 1991, Thurston and Kaya 1994, Koppenhöfer et al. 1995, Brown and Gaugler 1997, Shapiro et al. 2000, Glazer 2002, Millar and Barbercheck 2002, Georgis et al. 2006, Siegel et al. 2006, Koppenhöfer and Fuzy 2008). The goal of this research is to describe the influence of some abiotic factors on entomopathogenic nematodes in the soil.

\section{MATERIALS AND METHODS}

Field studies were carried out from 2010 to 2015 in north-west Poland, in diverse ecosystems and habitats, including forests, agro-ecosystems (farmlands, extensive meadows, and orchards), coastal dunes, xerothermic grasslands and urban greenery. The soil samples from most of the selected sites were taken three times during the high season (spring, summer and autumn). Each research surface was approximately $100 \mathrm{~m}^{2}$ and $20 \mathrm{~cm}$ deep; 50 individual samples were taken using Egner's stick, making the bulk sample approximately $600 \mathrm{~cm}^{3}$ in volume. In total, 384 soil samples were collected from 80 research plots (Table 1); the soil was transported to the laboratory in perforated bags. The presence of entomopathogenic nematodes in the soil samples were determined using a standard Galleria mellonella baiting technique (Bedding and Akhurst 1975, Mráček 1980). Each sample was distributed among 6 pots of a volume of $100 \mathrm{~cm}^{3}$ each. Then, 3 larvae of G. mellonella (the last stage of development, c. $20 \mathrm{~mm}$ ) were placed in every pot. Pots were placed in an incubator at $20^{\circ} \mathrm{C}$. After 3 days, the first control was performed, dead insects were removed and replaced by live ones (Bedding and Akhurst 1975). Dead larvae of G. mellonella were placed in modified White nematode traps (White 1929). The traps were kept in an incubator at $22^{\circ} \mathrm{C}$ for c. 1 week until obtaining the invasive larvae from dead larvae of G. mellonella.

The mortality of G. mellonellla insects infested with nematodes was assessed 5 days after the experiment was established. Isolated nematodes were preserved in $4 \%$ formalin and then identified based on morphological and morphometric features of invasive larvae (J3) and second generation adults (Hominik et al. 1997, Nguyen 2007). 


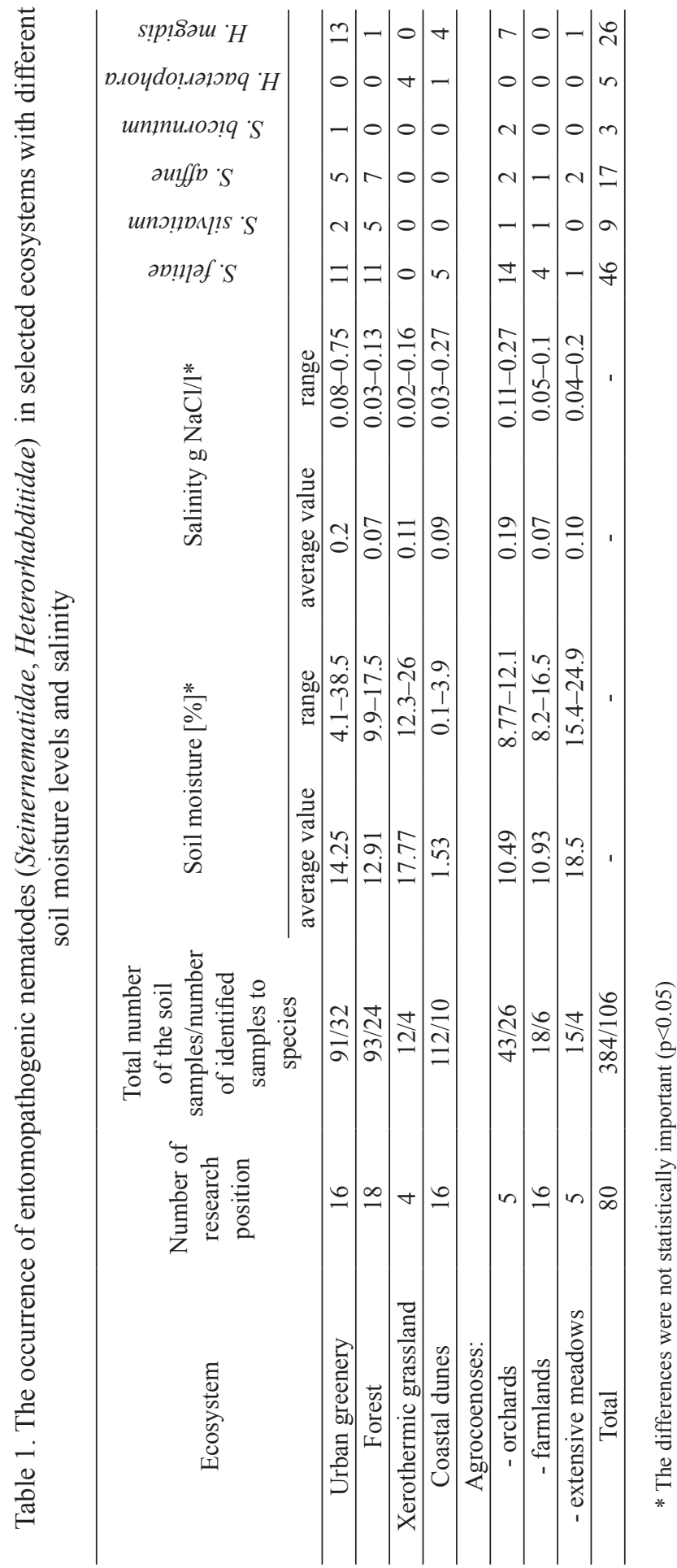


To evaluate how some abiotic factors can influence entomopathogenic nematodes and their biological activity in the soil, the following analyses were done:

1) potentiometric analysis of soil $\mathrm{pH}$ active acidity (in $\mathrm{H}_{2} \mathrm{O}$ ) and cation exchange acidity (in $1 \mathrm{~N} \mathrm{KCl}$ ) with proportions between soil and water/potassium chloride 1:2,5 after 24 hours of extraction;

2) determination of soil moisture in fresh soil samples with a dry-weight method using a Radwag WPE 30 S meter with automatic results showing in $\%$ at $106^{\circ} \mathrm{C}$ temperature;

3) conductometry analysis of electrical conductivity with a CPC-501 ELMETRON meter with a EC-60 conductometry sensor;

4) carbon, nitrogen, sulphur indication (CNS) analysis with an elemental Costech analysis instrument;

5) soil fraction analysis using Casagrande's method as modified by Prószyński (PN 04032: 1998).

Statistical analyses were performed with STATISTICA 6.0 software (StatSoft 1999) using: statistical significance tests on differences between structural factors (frequency of nematodes present in different ecosystems) and significance tests on differences between means, assuming a normal distribution of variables $(\mathrm{p}<0.05 \%)$. Pearson's chi square test was used to verify the relationship between nematode occurrence and biotic factors studied. The data is presented in Table 1, including mean values of variables and their standard deviations and ranges.

\section{RESULTS AND DISCUSSION}

The soil was taken from different types of ecosystems and categorised into three groups: sand, loamy sand and clay (Figure 1). Clay provided the lowest percentage of samples $(78 \%)$ with nematodes, while nematodes were found in $100 \%$ of the loamy sand samples. The difference was not statistically important $(\mathrm{p}<0.05)$. Entomopathogenic nematodes were the most present in sand: four were identified as Steinernematidae and two as Heterorhabditidae (Figure 1). Steinernema feltiae nematodes were present in every type of soils, but were most common in sand ( $64 \%$ of samples), while appearing in only $23 \%$ of clay and $13 \%$ of loamy sand samples. Some species, such as Heterorhabditis bacteriophora, were only present in sand; however, related H. megidis were predominant in clay $(68 \%)$. Soil $\mathrm{pH}$ levels ranged from very acidic to alkaline (Figure 2 ); almost $50 \%$ of the soil samples were acidic $(\mathrm{pH}=4.5-6.5)$, mainly from forests and crop fields; $37 \%$ were neutral, comprising the majority of samples from urban greenery, orchards and xerothermic grasslands; and 13\% of all samples were alkaline, mainly from sand dunes. Alkaline soil had the lowest percentage of samples with nematodes (approximately 14\%; Figure 2). The most flexible 
species with regard to habitat were $S$. feltiae and $H$. megidis, which were present in acidic, neutral and alkaline soil. However, the largest percentage $(67 \%)$ of isolate S. feltiae was from acidic soil, and more than $78 \%$ of $H$. megidis came from neutral soil. S. silvaticum, a species rarely observed in Poland, was present in acidic soil samples ( $\mathrm{pH}<4.5$; Figure 2). Neutral soil was preferred by $\mathrm{S}$. bicornutum. H. bacteriophora was present in completely different soil environments, both acidic and alkaline (Figure 2).

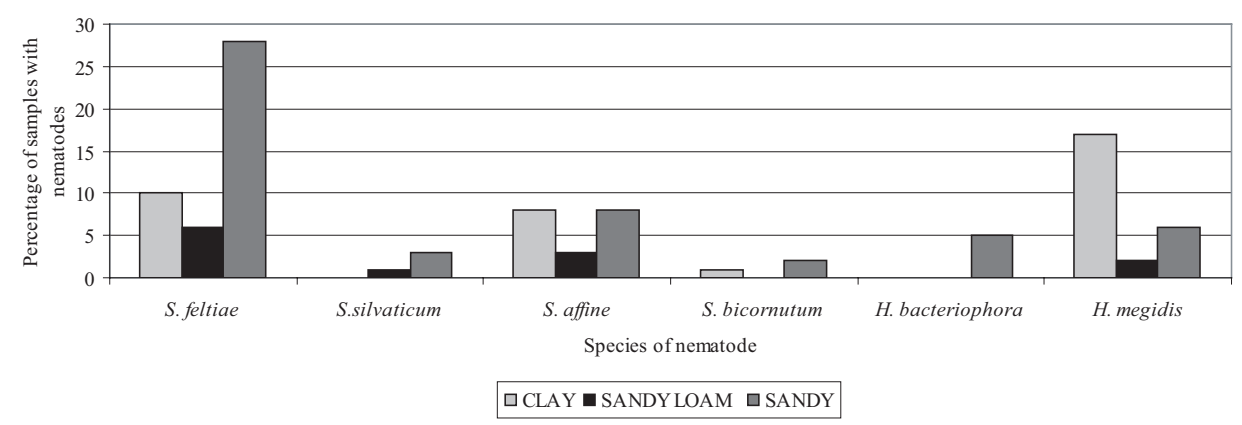

Fig. 1. The occurrence of entomopathogenic nematodes Steinernematidae and Heterorhabditidae in three types of soil

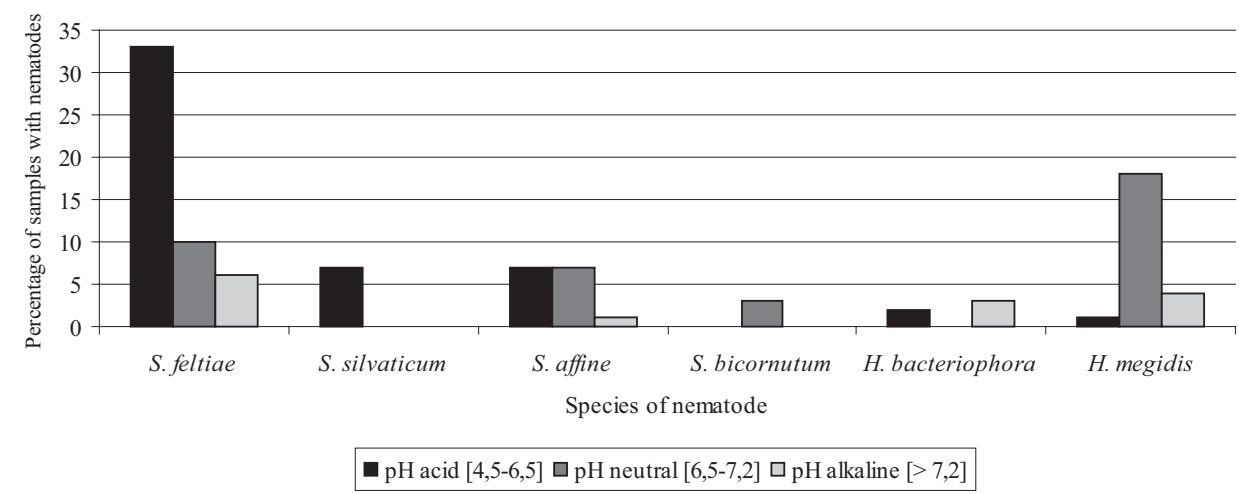

Fig. 2. The occurrence of entomopathogenic nematodes (Steinernematidae and Heterorhabditidae) in soil with different $\mathrm{pH}$ levels (scale: Mocek et al. 1997)

Most of the soil in the research had low humus content (about 1-5\%), wherein the percentage of samples with nematodes was the highest $(36 \%)$ in the soil with moderate humus content (approximately 2-5\%; Table 2). 29\% of the samples with nematodes were isolated from the soil with a strong presence of humus. Four species of nematodes ( $S$. feltiae, S. silvaticum, S. affine and $H$. megidis) were present in soils with extremely different organic content (Table 2). The highest species diversity was recorded in medium-humus soils, 
mainly from forests, orchards and meadows, which particularly favored $S$. feltiae and $H$. megidis nematodes (Table 2). S. bicornutum was only isolated from soils with an average humus content of 2 to $5 \%$ (Table 2 ).

Table 2. The occurrence of entomopathogenic nematodes (Steinernematidae, Heterorhabditidae) in selected ecosystems with different humus content

\begin{tabular}{|c|c|c|c|c|c|c|c|c|c|}
\hline \multirow[b]{2}{*}{ Humus content $[\%]^{*}$} & \multirow{2}{*}{ 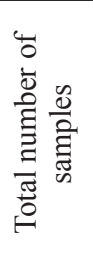 } & \multirow{2}{*}{ 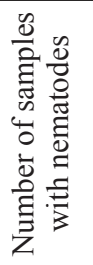 } & \multirow{2}{*}{ 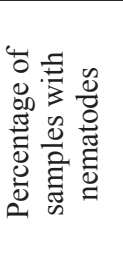 } & \multicolumn{4}{|c|}{ Steinernema } & \multicolumn{2}{|c|}{ Heterorhabditis } \\
\hline & & & & $\frac{8}{2}$ & 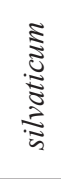 & ङ & $\begin{array}{l}5 \\
0 \\
0 \\
0 \\
0 \\
0 \\
0\end{array}$ & 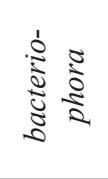 & 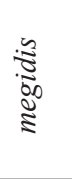 \\
\hline $\begin{array}{l}\text { Soils with low humus } \\
\text { content } 1-2 \%\end{array}$ & 139 & 25 & 18 & 11 & 1 & 6 & 0 & 3 & 4 \\
\hline $\begin{array}{l}\text { Soils with moderate } \\
\text { humus content } 2-5 \%\end{array}$ & 152 & 55 & 36 & 26 & 5 & 4 & 3 & 2 & 15 \\
\hline $\begin{array}{l}\text { Soils with moderate } \\
\text { humus content }>5 \%\end{array}$ & 93 & 26 & 29 & 9 & 3 & 7 & 0 & 0 & 7 \\
\hline Total & 384 & 106 & - & 46 & 9 & 17 & 3 & 5 & 26 \\
\hline
\end{tabular}

* Mocek et al.'s scale (1997)

All the research plots had comparably low-salinity soil, ranging from 0.01 to $0.75 \mathrm{~g} \mathrm{NaCl} / 1$. Average salinity was from 0.06 to $0.2 \mathrm{~g} \mathrm{NaCl} / 1$, a factor which was not significant for the presence of nematodes and species diversity in different ecosystems (Table 1).

Entomopathogenic nematodes were present in dune sand with very low moisture, averaging $1.53 \%$, and in soil from meadows and pastures with more than $22 \%$ moisture (Table 1 ).

Overall, less nematode species diversity was observed in soils with higher moisture. In these soils, the most common species of $S$. feltiae was not found; however, it was isolated, along with two other species of the Heterorhabditidae family, from the soil with the very low moisture average of $1.53 \%$ (Table 1). On dunes, with extremely low water content in the surface up to $30 \mathrm{~cm}, S$. affine was not present; it preferred soil with a moisture content of more than $10 \%$. Other species, such as $S$. bicornutum and S. silvaticum, were found in soils with an average moisture of 10.32 to $14.25 \%$ (Table 1 ).

Overall, loam soil samples had the largest percentage of samples with nematodes, but the greatest species diversity was found in sand soil.

Some nematodes were present in only one type of soil. For example, S. silvaticum and H. bacteriophora were present only in sand. In the clay, H. megidis was predominant, appearing in $47 \%$ of the samples. In all soil types, the presence of $S$. feltiae was recorded, though the species was most prevalent in sand soil. 
In addition, other researchers have identified an association of $S$. silvaticum with sandy soils and the presence of $S$. feltiae in all of the soil types studied (Mráček et al. 2005). The obtained results confirm the fact that entomopathogenic nematodes are present in different types of soils (Tumialis et al. 2016) and, as shown in the research in north-west Poland, may also be present in seasonal wetlands (Hominik and Briscoe 1990).

As clay content increases, nematode activity decreases (Kung et al. 1990, Koppenhöfer and Fuzy 2006), a result which is related to the size of the intermolecular space and the aeration (Gaugler and Kaya 1990, Hominik and Briscoe 1990). Shapiro-Ilan et al. (2002) reported that clay soils restrict nematode movement and are poorly aerated. The literature shows that entomopathogenic nematodes are more frequently found in sandy loam soils (Kary et al. 2009, Raheel et al. 2015), sandy soils (Kung et al. 1990) and loam sand soil (Stock et al. 1999), and their frequency increases (effect of infestation intensity) in areas with moderate precipitation (Koppenhöfer et al. 1997).

Physicochemical tests determined that $\mathrm{pH}$ soil level did not directly influence the presence of entomopathogenic nematodes: They were present in very acid soil $(\mathrm{pH}<4.5)$ and alkaline soil $(\mathrm{pH}>7.2)$. Their presence in a wide range of $\mathrm{pH}$ soil levels (from 4.6 to 8) has also been established by Hara et al. (1991), Griffin et al. (1994) and Stock et al. (1999). Other researchers have shown that the $\mathrm{pH}$ range of the soils from 4.5 to 5.7 was most considered tolerable by the EPNs (Nyasani et al. 2008).

Other researchers have shown that the vitality of invasive larvae is significantly reduced in very acidic and highly alkaline soils (Kung et al. 1990). As observed in the present research, some species of nematode, such as S. bicornutum, are only found in neutral soils, and others, such as S. silvaticum, only in acidic environments $(\mathrm{pH}<4.5)$. The research also shows that nematodes prefer soil with moderate humus content $(2-5 \%)$.

The observations of other researchers show that organic-rich soils provide a good shelter for entomopathogenic nematodes (Hominik and Briscoe 1990). An important factor for the migration of nematodes in soil is adequate soil moisture (Koppenhöfer et al. 1995, Půža and Mráček 2007).

The present study has shown that nematodes can be found in very low moisture soil in coastal dunes and high moisture soil in meadows and floodplains. Other researchers have also noted that low as well as excessive moisture levels have a negative effect on nematodes and their dispersion in the ground (Kondo and Ishibasi 1985). For example, the lowest percentage of nematodes in soil samples was recorded in soils with extreme moisture levels: over $22 \%$ moisture content ( $25 \%$ of samples) and less than $1.53 \%$ moisture content (10\% of samples).

Alekseev et al. (2006) recorded that the activity of IJs of S. carpocapsae in the soil upper layer $(1 \mathrm{~cm}$ depth) was strongly affected by the soil type. When the soil moisture was low and the number of nematodes found in the 
upper layer correspondingly low. Půža and Mráček (2007) suggest that low water content in the soil may slow the migration of invasive larvae from dead insects to the environment and influence nematode density in the soil. It has also been observed that during periodic droughts, the number of nematodes in the soil decreases significantly (Půža and Mráček 2005). However, Kung et al. (1991) and Hass et al. (2002) notice that in most soil, the presence of nematodes for a long period of time can cause excessive activity, resulting in the reduction of their energy supply. However, invasive larvae have numerous mitochondria and fat pads that temporarily protect them against starvation and other negative abiotic factors (Poinar 1990, Qui and Bedding 2000a, 2000b).

Considering the population of domestic nematodes predominating in particular habitats, it is appropriate to understand the biology and ecology of individual species of entomopathogenic nematodes, including their relations with the environment and specific hosts, for the effective use of these beneficial animals in integrated pest management programs.

\section{CONCLUSIONS}

1. The research has shown that nematodes are specific to the environment. The soil type and its physicochemical properties influence the presence of particular species of nematodes in the environment.

2. Entomopathogenic nematodes can live in soils with a variety of $\mathrm{pH}$ levels, from very acidic $(\mathrm{pH}<4.5)$ to alkaline $(\mathrm{pH}>7.2)$. Some species of nematode have specific habitat requirements. For example, the nematode Steinernema bicornutum was found only in neutral soils, and $S$. silvaticum only in acidic environments.

3. Loamy and sandy soils with moderate humidity (10-14\%) are the best habitats for the life and biological activity of the Steinernematidae Heterorhabditidae insectivorous nematodes.

4. Steinernema feltiae has the highest ecological flexibility, predisposing it to a wide application in pest control for a variety of agro- and biocoenoses habitats.

\section{REFERENCES}

[1] Adams, B.J., Fodor, A., Koppenhöfer, H.S., Stackebrandt, E., Stock, S.P., Klein, M.G., 2006. Biodiversity and systematics of nematode-bacterium entomopathogens. Biological Control: Theory and Applications in Pest Management 37(1): 32-49, DOI: 10.1016/j.biocontrol.2005.11.008.

[2] Alekseev, E., Glazer, I., Samish, M., 2006. Effect of soil texture and moisture on the activity of entomopathogenic nematodes against female Boophilus annulatus Ticks. Biocontrol, 51: 507-518, DOI: 10.1007/s10526-005-2935-9. 
[3] Bedding, R.A., Akhurst, R., 1975. A simple technique for the detection of insect parasitic rhabditid nematodes in soil. Nematologica, 21: 109-110.

[4] Brown, I.M., Gaugler, R., 1997. Temperature and humidity influence emergence and survival of entomopathogenic nematodes. Nematologica, 43: 363-375.

[5] Gaugler, R., Kaya, H.K., 1990. Entomopathogenic nematodes in biological control. CRC Press, Boca Raton, FL, USA, 54, p. 110.

[6] Georgis, R., Koppenhöfer, A.M., Lacey, L.A., Bélair, G., Duncan, L.W., Grewal, P.S., Samish, M., Tan, L., Torr, P., van Tol, R.W.H.M, 2006. Successes and failures in the use of parasitic nematodes for pest control. Biological Control, 38: 103-123.

[7] Glazer, I., 2002. Survival biology. In: R. Randy (eds.), Entomopathogenic nematology. CABI Publishing, Wallingford, Oxon, UK, pp. 196-181.

[8] Grewal, P.S., Ehlers, R-U., Shapiro-Ilan, D.I., 2005. Nematodes as biological control agents. CABI Publishing, Wallingford, p. 528.

[9] Grewal, P.S., 2012. Entomopathogenic nematodes as tools in integrated pest management. In: D.P Arbol, U. Shankar (eds.), Integrated Pest Management: Principles and Practice, CABI Publishing, Wallingford, UK, pp. 162-236.

[10] Griffin, C.T, Joyce, S.A., Dix, I., Burnell, A.M., Downes, M.J., 1994. Characterization of the entomopathogenic nematodes Heterorhabditis (Nematoda: Heterorhabditidae) from Ireland and Britain by molecular and cross-breeding techniques, and the occurrence of the genus in these islands. Fundamental and Applied Nematology, 17: 245-253.

[11] Hara, A., Gaugler, R., Kaya, H., LeBeck, L., 1991. Natural populations of entomopathogenic nematodes from the Hawaiian Islands. Environmental Entomology, 20: 211-216.

[12] Hass, B., Downes, M.J., Griffin, C.T., 2002. Persistence of four Heterorhabditis spp. isolates in soil: role of lipid reserves. Journal of Nematology, 34: 151-158.

[13] Hominik, W.M. 2002. Biogeography. In: R. Gaugler (ed.), Entomopathogenic Nematology, CABI Publishing, Wallingford, UK, pp. 115-143.

[14] Hominik, W.M., Briscoe, B.R., 1990. Occurrence of entomopathogenic nematodes (Rhabditida: Steinernematidae and Heterorhabditidae) in British soil. Parasitology, 100: 295-302.

[15] Hominik, W.M., Briscoe, B.R., del Pino, F.G., Heng, J., Hunt, D.J., Kozodoy, E., Mráček Z., Nguyen, K.B., Reid, A.P., Spiridonov, S., Stock, P., Sturhan, D., Waturu, C., Yoshida, M., 1997. Biosystematics of entomopathogenic nematodes: current status, protocols and definitions. Journal of Helminthology, 71: 271-298.

[16] Kary, N.E., Niknam, G., Griffin, C.T., Mohammadi, S.A, Mohammadi, M., 2009. A survey of entomopathogenic nematodes of the families Steinernematidae and Heterorhabditidae (Nematoda: Rhabditida) in the North-West of Iran. Nematology, 11(1): 107-116.

[17] Kaya, H.K., 1990. Soil Ecology. In: R. Gaugler, K.H. Kaya (eds.), Entomopathogenic Nematodes in Biological Control, CRC Press, Boca Raton, pp. 93-115.

[18] Kondo, E., Ishibashi, N., 1985. Effects of soil moisture on the survival and infectivity of the entomogenous nematode, Steinernema feltiae (DD-136). Proceedings of the Association for Plant Protection of Kyushu, 31: 186-190.

[19] Koppenhöfer, A.M., Kaya, H.K, Taormino S.P., 1995. Infectivity of entomopathogenic nematodes (Rhabditida: Steinernematidae) at different soil depths and moistures. Journal of Invertebrate Pathology, 65: 193-199.

[20] Koppenhöfer, A.M., Baur, M.E., Stock, S.P., Yul, H., Chinnasri, B., Kaya, H.K., 1997. Survival of entomopathogenic nematodes within host cadavers in dry soil. Applied Soil Ecology, 6: 231-240.

[21] Koppenhöfer, A.M, Fuzy, E.M., 2006. Effect of soil type on infectivity and persistence of the entomopathogenic nematodes Steinernema scarabaei, Steinernema glaseri, Heterorhabditis zealandica, and Heterorhabditis bacteriophora. Journal of Invertebrate Pathology, 92: 11-22.

[22] Koppenhöfer, A.M., Fuzy, E.M., 2008. Attraction of four entomopathogenic nematode species to four white grub species. Journal of Invertebrate Pathology, 99: 227-234. 
[23] Kung, S.P., Gaugler, R., Kaya, H.K., 1990. Soil type and entomopathogenic nematode persistence. Journal of Invertebrate Pathology, 55(3): 410-406.

[24] Kung, S.P., Gaugler, R., Kaya, H., 1991. Effects of soil temperature, moisture and relative humidity on entomopathogenic nematode persistence. Journal of Invertebrate Pathology, 57 : 242-249.

[25] Millar, L.C., Barbercheck, M.E., 2002. Effects of tillage practices on entomopathogenic nematodes in a corn agroecosystem. Biological Control, 25: 1-11.

[26] Mocek, A., Drzymała, S., Maszner, P., 1997. Geneza, analiza i klasyfikacja gleb. Wydawnictwo Akademii Rolniczej, Poznań, p. 416.

[27] Mráček, Z., 1980. The use of Galleria traps for obtaining nematode parasites of insects in Czechoslovakia (Lepidoptera: Nematoda, Steinernematidae). Acta Entomologica Bohemoslovaca, 77: 378-382.

[28] Mráček, Z., Bečváŕ, S., Kindlmann, P., 1999. Survey of entomopathogenic nematodes from the families (Nematoda: Rhabditida) in the Czech Republic. Folia Parasitologica, 46: 145-148.

[29] Mráček, Z., Bečvár, S., 2000. Insect aggregations and entomopathogenic nematode occurrence. Nematology, 2(3): 297-301.

[30] Mráček, Z., Bečvář, S., Kindlmann, P., Jersáková, J., 2005. Habitat preference for entomopathogenic nematodes, thier insect hosts and new faunistic records for the Czech Republic. Biological Control, 34: 27-37.

[31] Nguyen, K.B., 2007. Methodology, morphology and identification. In: K.B. Nguyen, D.J. Hunt (eds.), Entomopathogenic nematodes: Systematics, Phylogeny and Bacterial Symbionts. Nematology Monographs and Perspectives. Brill Leiden-Boston, 5: 59-119.

[32] Nyasani, J.O., Kimenju, J.W., Olubayo, F.M., Shibairo, S.I. Mutua, G.K., 2008. Occurrence of entomopathogenic nematodes and their potential in the management of diamondback moth in Kale. Asian Journal of Plant Sciences, 7: 314-318.

[33] Peters, A., 1996. The natural host range of Steinernema and Heterorhabditis spp. and their impact of insect populations. Biocontrol Science and Technology, 6: 389-402, DOI: 10.1080/09583159631361.

[34] PN 04032: 1998. Soils and mineral deposits - Sampling and determination of granulometric composition.

[35] Poinar, G.O. Jr., 1990. Taxonomy and Biology of Steinernematidae and Heterorhabditidae. In: R. Gaugler, H.K. Kaya (eds.), Entomopathogenic Nematodes in Biological Control. CRC Press, Boca Raton, pp. 23-61.

[36] Půža, V., Mráček, Z., 2005. Seasonal dynamics of entomopathogenic nematodes of the genera Steinernema and Heterorhabditis as a response to abiotic factors and abundance of insect hosts. Journal of Invertebrate Pathology, 89: 116-122.

[37] Půža, V., Mráček, Z., 2007. Natural population dynamics of entomopathogenic nematode Steinernema affine (Steinernematidae) under dry conditions: Possible nematode persistence within host cadavers? Journal of Invertebrate Pathology, 96: 89-92.

[38] Qui, L., Bedding, R.A., 2000a. Energy metabolism and its relation to survival and infectivity of infective juveniles of Steinernema carpocapsae under aerobic conditions. Nematology, 2: 551-559.

[39] Qui, L., Bedding, R.A., 2000b. Energy metabolism and survival of the infective juveniles of Steinernema carpocapsae under oxygen-deficient conditions. Journal of Nematology, 32: 271-280.

[40] Raheel, M., Javed, N., Khan, S.A., Achmed, S., 2015. Impact of soil texture on the infectivity of different species of entomopathogenic nematodes against greater wax moth (Galleria mellonella L.). Pakistan Journal of Phytopathology, 27(02): 189-192.

[41] Shapiro, D.I., McCoy, C.W., Fares, A., Obreza, T., Dou, H., 2000. Effects of soil type on virulence and persistence of entomopathogenic nematodes in relation to control of Diaprepes abbreviatus. Environmental Entomology, 29: 1083-1087. 
[42] Shapiro-Ilan, D.I., Gaugler, R., Tedders, W.L., Brown, I., Lewis, E.E., 2002. Optimization of inoculation for in vivo production of entomopathogenic nematodes. Journal of Nematology, 34: 343-350.

[43] Siegel, J., Lacey, L.A., Higbee, B.S., Noble, P., Fritts, R. Jr., 2006. Effect of application rates and abiotic factors on Steinernema carpocapsae for control of overwintering navel orangeworm (Lepidoptera: Pyralidae, Amyelois transitella) in fallen pistachios. Biological Control, 36: 324-330.

[44] Stock, S.P., Pryor, B.M., Kaya, H.K., 1999. Distribution of entomopathogenic nematodes (Steinernematidae and Heterorhabditidae) in natural habitats in California, USA. Biodiversity and Conservation, 8: 535-549.

[45] Thurston, G.S., Ni., Y., Kaya, H.K., 1994. Influence of salinity on survival and infectivity of entomopathogenic nematodes. Journal of Nematology, 26: 345-351.

[46] Tumialis, D., Pezowicz, E., Skrzecz, I., Mazurkiewicz, A., Maszewska, J., Jarmuł-Pietraszczyk, J., Kucharska, K., 2016. Occurrence of entomopathogenic nematodes in Polish soils. Ciência Rural, 46: 1126-1129.

[47] White, G.F., 1929. A method for obtaining infective nematode larvae from cultures. Science, 66: 302-303, DOI: 10.1126/science.66.1709.302-a. 